\title{
High methane yields in anaerobic digestion of the cyanobacterium Pseudanabaena sp.
}

Sara P. Cuellar-Bermudez ${ }^{1 \mathrm{a}}$, Jose Antonio Magdalena ${ }^{2 \mathrm{a}}$, Koenraad Muylaert ${ }^{1}$, Cristina

\author{
Gonzalez-Fernandez ${ }^{2}$ \\ ${ }^{1}$ KU Leuven, Campus KULAK, Kortrijk, Belgium \\ ${ }^{2}$ Biotechnological Processes Unit, IMDEA Energy, Madrid, Spain
}

${ }^{a}$ These authors contributed equally to this work.

* Sara.cuellarbermudez@kuleuven.be

\begin{abstract}
Microalgae are a novel biomass feedstock for the production of biogas through anaerobic digestion. However, anaerobic digestion of microalgal biomass often suffers from low methane yields due to their rigid cell walls. In contrast to eukaryotic microalgae, prokaryotic cyanobacteria have a weaker cell wall and might be more attractive as feedstock for anaerobic digestion. Nevertheless, feedstock biomass composition influences the anaerobic digestion process. In cyanobacteria, nitrogen is a key nutrient for which availability induces changes in the biomass composition. In this study, the cyanobacterium Pseudanabaena sp. CY14-1 was cultivated at different nitrogen concentrations $\left(14,42\right.$ and $\left.56 \mathrm{mg} \mathrm{N} \mathrm{L}^{-1}\right)$ to achieve biomass with a variable carbohydrate content $(61,38$ and $23 \%$ dry weight, respectively). Anaerobic digestion of these three types of Pseudanabaena sp. CY14-1 biomass was performed in batch experiments to evaluate the effect of biomass composition on methane yields. During the first days of the experiment, the methane yield of the biomass was comparable irrespective of the carbohydrate content. The final methane yield, however, was higher for the biomass with $23 \%$ carbohydrate
\end{abstract}


content $\left(251 \mathrm{~mL} \mathrm{CH}_{4} \mathrm{~g}^{-1} \mathrm{COD}_{\text {in }}\right)$ than for the biomass with 38 and $61 \%$ carbohydrates $(226$ and $215 \mathrm{~mL} \mathrm{CH}_{4} \mathrm{~g}^{-1} \mathrm{COD}_{\text {in }}$, respectively). In contrast, $61 \%$ carbohydrate-rich biomass showed the highest hydrolysis constant $\left(0.21 \mathrm{day}^{-1}\right)$ among the three types of Pseudanabaena sp. CY14-1 biomass. Methane yields achieved with these three biomasses are higher than those reported for some eukaryotic microalgae species, highlighting the potential of cyanobacteria as biomass feedstock for anaerobic digestion.

Keywords: Cyanobacteria, nitrogen concentration, carbohydrates, biogas.

\section{Introduction}

Biogas production through anaerobic digestion $(\mathrm{AD})$ is a simple and low-cost method to convert biomass feedstocks into a renewable source of energy [1]. Substrates commonly used for AD include animal manure, lignocellulosic materials from agricultural waste, food waste, or sludge generated during wastewater treatment [2,3]. Eukaryotic microalgae and prokaryotic cyanobacteria represent an alternative renewable biomass feedstock for biogas generation through AD [4,5]. Microalgae and cyanobacteria are highly productive photosynthetic microorganisms that can be cultivated on non-arable lands [5]. Moreover, production of microalgae or cyanobacterial biomass can be coupled to $\mathrm{CO}_{2}$ removal from flue gasses and recovery of $\mathrm{N}$ and $\mathrm{P}$ from wastewater [5].

Most studies on $\mathrm{AD}$ of photosynthetic microorganisms have focused on eukaryotic microalgae species belonging to the genera Chlamydomonas, Chlorella, Scenedesmus, and Nannochloropsis 
[6-10]. Their methane yields ranged from 81 to $185 \mathrm{~mL} \mathrm{CH}_{4} \mathrm{~g}^{-1} \mathrm{COD}_{\text {in }}$ [7,9]. Relatively few reports have been published on $\mathrm{AD}$ of prokaryotic cyanobacteria species, namely Anabaena, Aphanizomenon, Arthrospira, Borzia, and Synechocystis $[8,9,11]$. Their methane yields range from 160 to $261 \mathrm{~mL} \mathrm{CH}_{4} \mathrm{~g}^{-1} \mathrm{COD}_{\text {in, }}$ which are higher than those of eukaryotic microalgae [8].

The first stage of the AD process, the hydrolysis stage, is often described as the limiting step of the AD process [12]. Therefore, efficient hydrolysis of the organic matter is key to improve methane yields [12]. Prokaryotic cyanobacteria have a relatively simple cell wall composition when compared to eukaryotic microalgae or lignocellulosic materials, which facilitates the hydrolytic stage of $\mathrm{AD}[4]$. The use of lignocellulosic materials and eukaryotic microalgae requires biomass pre-treatments to enhance hydrolytic rates, resulting in an increase of the biogas production costs $[8,13-15]$.

In addition to cell wall complexity, the methane yield of $\mathrm{AD}$ is influenced by the biomass macromolecular composition, more specifically, the relative content of proteins, carbohydrates, and lipids in the biomass. For instance, the use of biomass with high protein content releases ammonia during $\mathrm{AD}$, leading to inhibition of methanogens. The use of carbohydrate-rich biomass can result in the accumulation of volatile fatty acids, decreasing the $\mathrm{pH}$ in the digester and, thus, inhibiting methanogens. Both situations would destabilize the AD microbiome resulting in low methane yields [16]. While lipids are easily degradable, at high concentrations they can cause microbial inhibition resulting in mass transfer problems in the digesters [17]. Therefore, biomass macromolecular composition is a key parameter to ensure high methane yields. The macromolecular composition of cyanobacterial biomass is highly variable and is influenced by the 
nutrient supply. For instance, the cyanobacterium Arthrospira accumulates up to $68 \%$ dry weight protein when nitrogen concentration in the cultivation medium is sufficient or $73 \%$ dry weight carbohydrate when its concentration is markedly reduced [18,19].

In this study, we investigated AD of biomass of the cyanobacterium Pseudanabaena sp. CY14-1. We selected this strain because this species occurs naturally in microalgae-based wastewater treatment systems and is recognized for its high nutrient uptake capacity [20-23]. Interestingly, this species has a weak cell wall [24], which should facilitate the AD process. Therefore, Pseudanabaena sp. CY14-1 biomass cultivated in wastewater is a promising feedstock for biogas production using AD. Like many other prokaryotic cyanobacteria, Pseudanabaena species have been reported to accumulate carbohydrates or proteins depending on the available nitrogen concentration in the medium [25]. In this study, Pseudanabaena sp. CY14-1 was cultivated under variable nitrogen concentrations to modify its macromolecular biomass composition. We subsequently evaluated the methane yield from the types of biomass and compared it to published data on prokaryotic cyanobacteria and eukaryotic microalgae.

\section{Methods}

\subsection{Pseudanabaena cultivation and biomass production}

The cyanobacterium Pseudanabaena sp. CY14-1 (from now Pseudanabaena) was isolated from a freshwater surface sediment of a reservoir at KU Leuven campus Kortrijk as described by [26]. 
For identification, genomic DNA was extracted, and sequencing of the 16S rRNA gene was performed (GenBank accession number MF029647). The cyanobacteria primers CYA106F and CYA781R were used to amplify a partial sequence of the 16S rRNA gene [26,27]; sequencing was performed by GATC, and the obtained sequence was compared to gene sequences available in GenBank using NCBI Blast [26].

Pseudanabaena was cultivated in $1 \mathrm{~L}$ glass bottles stirred and mixed by aeration with $0.2 \mu \mathrm{m}$ filtered air $\left(5 \mathrm{~L} \mathrm{~min}^{-1}\right)$. Cultures were placed in a temperature-controlled room $\left(22{ }^{\circ} \mathrm{C}\right)$ and irradiated with daylight fluorescent tubes, providing a light intensity of $100 \mu \mathrm{E} \mathrm{m}^{-2} \mathrm{~s}^{-1}$ at the surface of the bottle. Three nitrogen concentrations $\left(56,42\right.$ and $\left.14 \mathrm{mg} \mathrm{L}^{-1} \mathrm{~N}\right)$, were supplied into the cultures, run in duplicate, in the form of $\mathrm{NaNO}_{3}$ (treatment $\mathrm{A}, \mathrm{B}$, and $\mathrm{C}$, respectively). These different nitrogen concentrations were selected based on exploratory experiments to achieve biomass with different carbohydrate content. The concentration of the rest of the nutrients as in the standard WC medium was: $36.8 \mathrm{mg} \mathrm{L}^{-1} \mathrm{CaCl}_{2} \bullet 2 \mathrm{H}_{2} \mathrm{O}, 36.9 \mathrm{mg} \mathrm{L}^{-1} \mathrm{MgSO}_{4} \cdot 7 \mathrm{H}_{2} \mathrm{O}, 12.6 \mathrm{mg} \mathrm{L}^{-1}$ $\mathrm{NaHCO}_{3}, 28.4 \mathrm{mg} \mathrm{L}^{-1} \mathrm{Na}_{2} \mathrm{SiO}_{3} \bullet 9 \mathrm{H}_{2} \mathrm{O}, 8.7 \mathrm{mg} \mathrm{L}^{-1} \mathrm{~K}_{2} \mathrm{HPO}_{4}$, trace metals and vitamins [28]. Medium's pH was set to 8.0 but not further controlled. Biomass was harvested at day 6 of cultivation. Aeration in the glass bottles was stopped allowing cells settling. Settled biomass was collected and centrifuged at $2000 \mathrm{~g}$ for $5 \mathrm{~min}$ prior to AD tests.

Pseudanabaena's specific growth rate $\mu\left(\right.$ day $\left.^{-1}\right)$ for each treatment was calculated using the following equation (Eq. 1):

$$
\mu=\operatorname{Ln}\left(X_{t} / X_{0}\right) /\left(t-t_{0}\right) \quad \boldsymbol{E q} \cdot \boldsymbol{1}
$$


Where $\mathrm{X}_{0}\left(\mathrm{mg} \mathrm{L}^{-1}\right)$ is the initial biomass concentration at day zero $\left(\mathrm{t}_{0}\right)$ and, $\mathrm{X}_{\mathrm{t}}\left(\mathrm{mg} \mathrm{L}^{-1}\right)$ is the accumulated biomass concentration at a specific time (t) of six days.

\subsection{Anaerobic digestion}

Anaerobic sludge was collected at the wastewater treatment plant of Valladolid, Spain. The sludge had a total solids (TS) concentration of $36 \mathrm{~g} \mathrm{~L}^{-1}$ and volatile solids (VS) with respect to TS of 60 \%. AD experiments were conducted in batch mode during 29 days in $120 \mathrm{~mL}$ glass digesters containing $70 \mathrm{~mL}$ working volume. Mesophilic temperature $\left(35^{\circ} \mathrm{C}\right)$ and $150 \mathrm{rpm}$ were set to promote the growth of anaerobic microorganisms. To ensure anaerobic conditions, oxygen was removed from digesters by purging helium. Freshly harvested Pseudanabaena biomass was mixed with anaerobic sludge in order to obtain a chemical oxygen demand to volatile solids (COD/VS) ratio of $0.5\left(\mathrm{~g} \mathrm{~g}^{-1}\right)$. Digesters were run in triplicate. The initial $\mathrm{pH}$ was set to 7.5 but was not controlled during the experiment. However, a final concentration of $1.3 \mathrm{~g} \mathrm{~L}^{-1} \mathrm{CaCO}_{3}$ was added as buffer per digester. The volume of biogas produced by the substrates was calculated under standard temperature and pressure $\left(0{ }^{\circ} \mathrm{C}\right.$ and $\left.1 \mathrm{~atm}\right)$ by measuring the pressure of the headspace in the bottles. Bottles containing only anaerobic sludge were run as blanks for quantification of endogenous methane production, and control tests using ethanol as substrate were run to check the correct performance of the anaerobic microorganisms. In order to calculate methane yields, biogas composition was analyzed by gas chromatography (Clarus 580 GC, PerkinElmer, USA) coupled to a thermal conductivity detector equipped with HSN6-60/80 Sulfinert P (7' x 1/8") and MS13X409SF2 40/60 P (9' x 1/8") packed columns (PerkinElmer, USA). Helium was used as carrier gas at 
a flow rate of $30 \mathrm{~mL} \mathrm{~min}^{-1}$. The injector, oven and detector temperatures were 80,62 , and $200{ }^{\circ} \mathrm{C}$, respectively. The injected sample volume was $100 \mu \mathrm{L}$.

The hydrolysis constant for AD of Pseudanabaena biomass was calculated based on the firstorder equation (Eq. 2), as reported by [29]:

$$
B(t)=B_{\infty}\left[1-\exp \left(-k_{H}\left(t-L_{P}\right)\right)\right] \boldsymbol{E} \boldsymbol{q} .2
$$

Where $B(t)$ is the accumulated methane yield ( $\left.\mathrm{mL} \mathrm{CH}_{4} \mathrm{~g}^{-1} \mathrm{COD}_{\text {in }}\right), \mathrm{B}_{\infty}$ is the theoretical potential methane yield ( $\left.\mathrm{mL} \mathrm{CH}_{4} \mathrm{~g}^{-1} \mathrm{COD}_{\mathrm{in}}\right), k_{H}$ the hydrolysis constant (days ${ }^{-1}$ ), $L_{P}$ the lag phase (days) and $t$ the elapsed time (days).

\subsection{Analytical methods}

To quantify the biomass produced, Pseudanabaena growth was monitored by measuring absorbance at $750 \mathrm{~nm}$ corresponding to optical density. Dry weight (DW) was gravimetrically determined by filtration of a culture volume with a known optical density over a pre-weighed Whatman filter (GF/C) followed by overnight drying at $105^{\circ} \mathrm{C}$. Optical density (OD) and biomass DW were linearly correlated following Eq. 3.

$$
\text { Biomass concentration }\left(m g L^{-1}\right)=584\left(O D_{750} \mathrm{~nm}\right)-17 \quad \text { Eq. } 3
$$

Carbohydrate content in the biomass was determined by the phenol-sulphuric acid method using glucose as standard [30]. Protein content was determined by the Lowry assay using bovine serum albumin as standard [31]. Lipid content in biomass was determined as reported by Mishra et al., 
[32] using canola oil as standard. Nitrogen concentration in the cultivation medium was determined by the salicylic-sulphuric acid method using $\mathrm{NaNO}_{3}$ as standard [33]. Chemical oxygen demand (COD) was determined by colorimetric analysis using commercial test kits (Merck, ISO 15705).

\subsection{Statistics}

Statistical differences among treatments were evaluated by one-way analysis of variance (ANOVA) and the post hoc Tukey test (IBM SPSS Statistics, USA). A $p$-value lower than the significance level $(\alpha) 0.05$ was considered to be significant.

\section{Results and discussion}

\subsection{Pseudanabaena cultivation and biomass production}

Biomass production, as estimated from optical density at $750 \mathrm{~nm}$, in the three nitrogen treatments was not affected by the nitrogen concentration supplied in the medium, and the stationary phase of each treatment started on day 6 (Figure 1.A). The growth rate as estimated from the increase in optical density was also not statistically different among the treatments $(p=0.392)$. However, the nitrogen concentration in the culture medium had a strong effect on the macromolecular biomass composition in terms of proteins and carbohydrates (Table 1). 
Treatment A had sufficient nitrogen during cultivation (Figure 1.B) and was mainly composed of protein $(61 \pm 10.1 \% \mathrm{DW})$ with only $23 \pm 6.8 \% \mathrm{DW}$ carbohydrate. By day 5 , treatment B consumed the $42 \mathrm{mg} \mathrm{L}^{-1}$ nitrogen supplied (Figure 1.B), accumulating $38 \pm 3.2 \% \mathrm{DW}$ carbohydrate. Finally, treatment $\mathrm{C}$ with the lowest initial nitrogen concentration $\left(14 \mathrm{mg} \mathrm{N} \mathrm{L}^{-1}\right)$, accumulated $61 \pm 2.1 \%$ DW carbohydrate and was nitrogen-limited from day 2 of cultivation (Figure 1.B). Similar to our results, up to $10 \mathrm{mg} \mathrm{L}^{-1}$ day $^{-1}$ consumption of nitrogen has been previously reported for Pseudanabaena [22]. In addition, carbohydrate accumulation as a response to nitrogen limitation has been reported in different cyanobacteria species, including Pseudanabaena [18,25]. Comparable to our results, biomass accumulation during nitrogen starvation was not affected in the cyanobacteria Arthrospira sp., accumulating up to $73 \%$ DW carbohydrate after 10 days of cultivation despite the nitrogen concentration tested [18]. Lipid content in Pseudanabaena biomass ranged from 8 to $10 \%$ DW and was not statistically different among the treatments $(p=0.190)$. Thus, nitrogen limitation did not promote lipid accumulation in Pseudanabaena, as similarly reported for other cyanobacteria species [11,18,34]. 

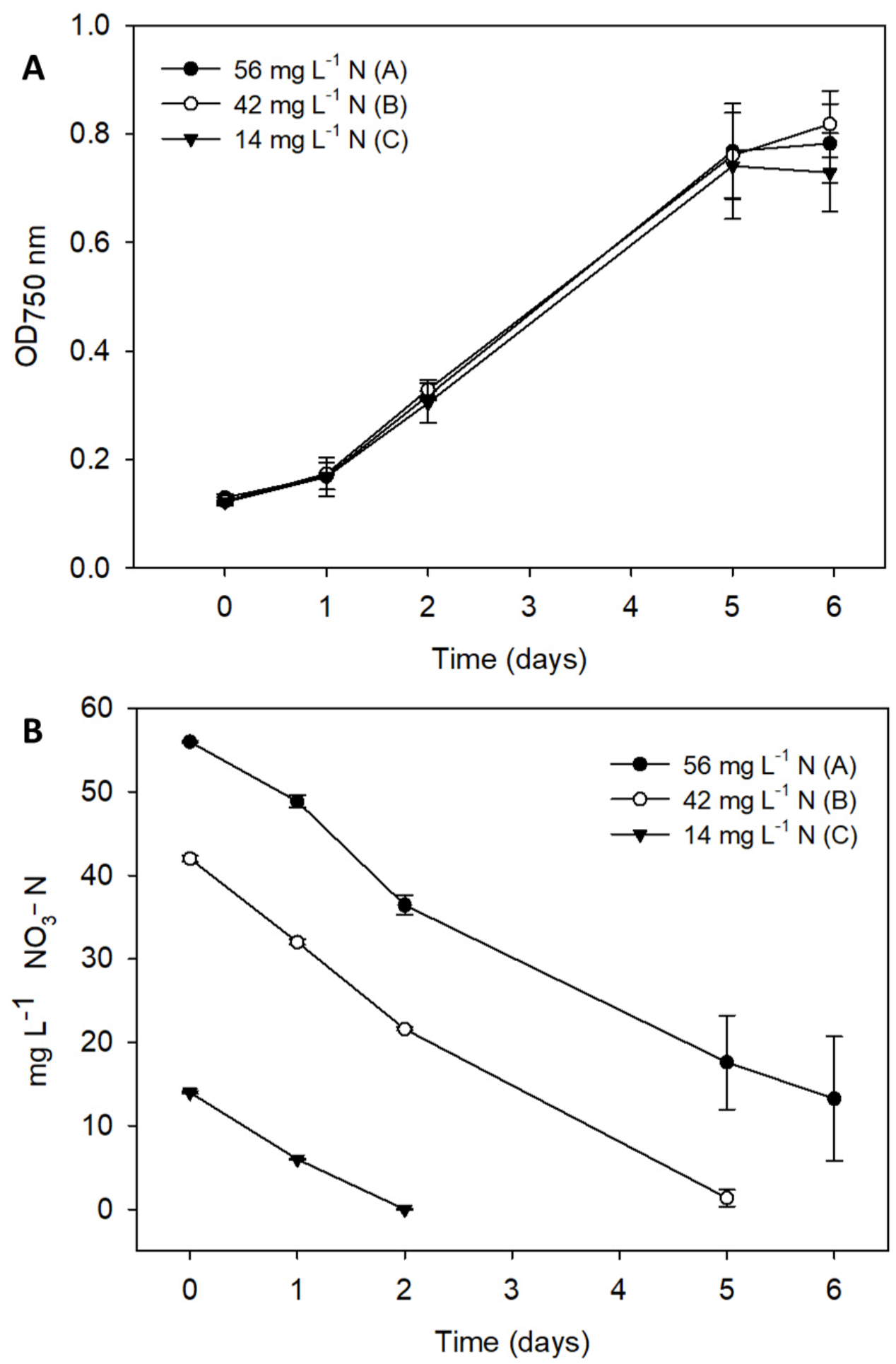

Figure 1: (A) Pseudanabaena growth measured by absorbance (optical density) at $750 \mathrm{~nm}$ $(\mathrm{n}=2)$. (B) Nitrogen concentration in Pseudanabaena treatments during cultivation $(\mathrm{n}=2)$. Data represent averages and standard deviations. 
Table 1: Pseudanabaena growth parameters and biomass composition determined at day 6 of cultivation. Data represent averages and standard deviations $(n=2)$. Superscripts represent a significant difference in the results $(\alpha=0.05)$.

\begin{tabular}{lccc}
\hline & Treatment A & Treatment B & Treatment C \\
\hline Initial nitrogen concentration $\left(\mathrm{mg} \mathrm{L}^{-1}\right)$ & $56 \pm 0.1$ & $42 \pm 0.4$ & $14 \pm 0.2$ \\
Biomass concentration $\left(\mathrm{mg} \mathrm{L}^{-1}\right)$ & $440 \pm 33^{\mathrm{a}}$ & $461 \pm 36^{\mathrm{a}}$ & $409 \pm 42^{\mathrm{a}}$ \\
Growth rate $\left(\right.$ day $\left.^{-1}\right)$ & $0.34 \pm 0.01^{\mathrm{a}}$ & $0.36 \pm 0.001^{\mathrm{a}}$ & $0.34 \pm 0.02^{\mathrm{a}}$ \\
\% Carbohydrates (DW) & $23 \pm 6.8^{\mathrm{b}}$ & $38 \pm 3.2^{\mathrm{b}}$ & $61 \pm 2.1^{\mathrm{a}}$ \\
\% Proteins (DW) & $61 \pm 10.1^{\mathrm{b}}$ & $46 \pm 5.6^{\mathrm{ab}}$ & $18 \pm 1.1^{\mathrm{a}}$ \\
\% Lipids (DW) & $11 \pm 0.1^{\mathrm{a}}$ & $10 \pm 1.6^{\mathrm{a}}$ & $8 \pm 0.2^{\mathrm{a}}$ \\
\hline
\end{tabular}

DW refers to dry weight

\subsection{Anaerobic digestion}

Methane yield was evaluated in batch AD assays for 29 days. In all treatments, a rapid increase in methane yield from 60 to $140 \mathrm{~mL} \mathrm{CH}_{4} \mathrm{~g}^{-1} \mathrm{COD}_{\text {in }}$ was observed between days 2 to 5 (Figure 2). This rapid increase in methane yields indicated that Pseudanabaena biomass was highly digestible, regardless of the carbohydrate and protein content. However, from day 5 onwards, methane yields differed statistically ( $p=0.01$ ) among the three different Pseudanabaena biomass (Table 2). Biomass from treatment A with $23 \%$ DW carbohydrate produced the highest methane yield of $251 \pm 7.2 \mathrm{~mL} \mathrm{CH}_{4} \mathrm{~g}^{-1} \mathrm{COD}_{\text {in. }}$. In contrast, methane yield reached only $226 \pm 5.3 \mathrm{~mL} \mathrm{CH}_{4} \mathrm{~g}^{-1} \mathrm{COD}_{\text {in }}$ and $215 \pm 1.4 \mathrm{~mL} \mathrm{CH}_{4} \mathrm{~g}^{-1} \mathrm{COD}_{\text {in }}$ for biomass from treatments $\mathrm{B}$ and $\mathrm{C}$ with $38 \%$ and $61 \% \mathrm{DW}$ 
carbohydrates, respectively. Methane concentration in biogas is commonly reported around 50-70 $\% \mathrm{v} \mathrm{v}^{-1}[35]$. Despite the differences in methane yields among Pseudanabaena biomass, methane concentration in biogas was not statistically different among treatments $(p=0.158)$ and contained around 61-70\% v v ${ }^{-1}$ methane for all substrates (Table 2). Ash content for Pseudanabaena was below $5 \%$ DW for the three types of biomass (data not shown), similar to that of other cyanobacteria species, including Arthrospira and Synechocystis [36,37]. AD experiments were conducted based on the COD/VS ratio $\left(0.5 \mathrm{~g} \mathrm{~g}^{-1}\right)$. Given the low ash content, the cyanobacterial biomass used was suitable for AD since only the organic matter (represented by VS or COD) is converted to methane.

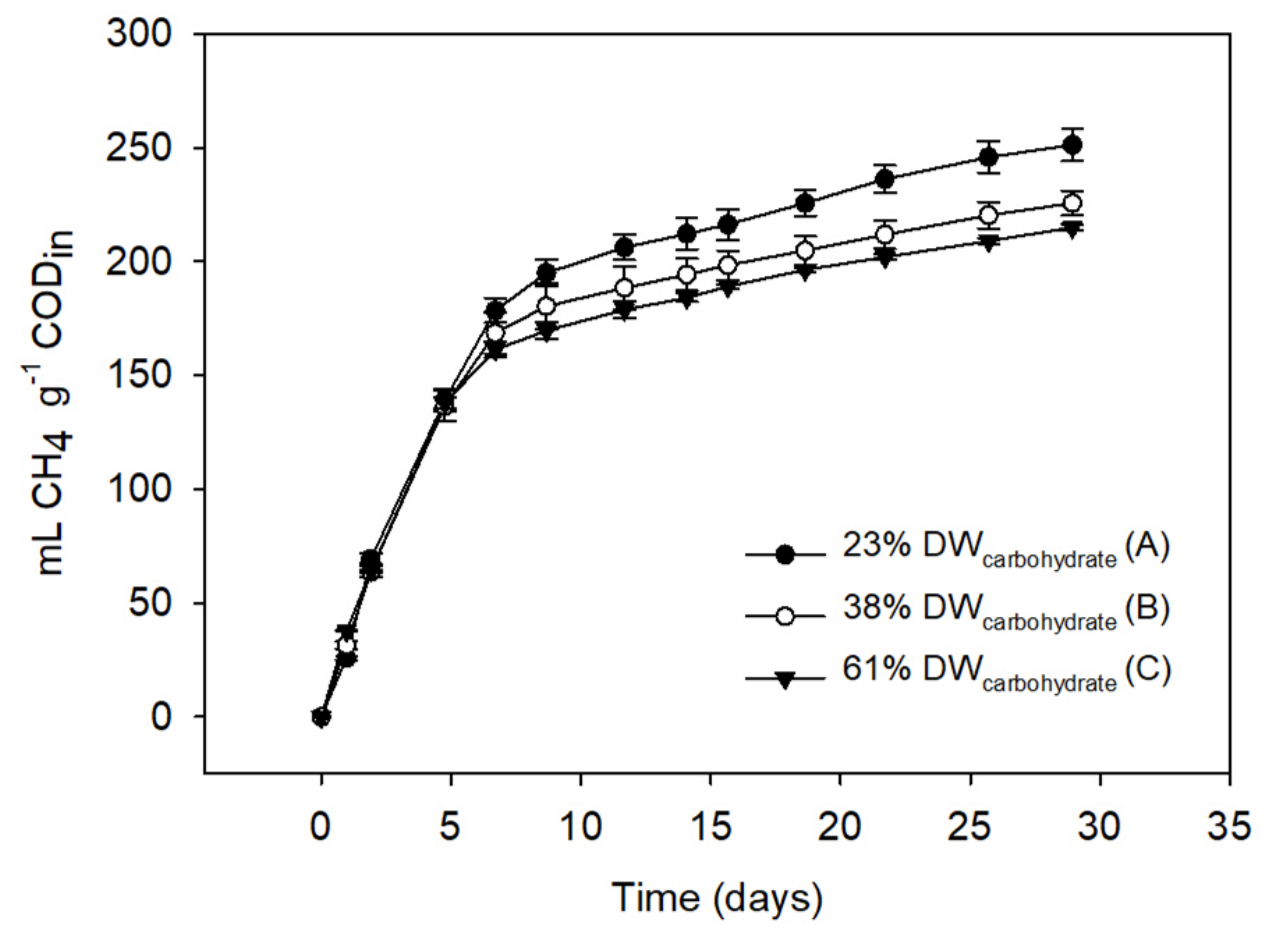

Figure 2: Methane yields achieved when digesting Pseudanabaena biomass with different carbohydrate content. DW refers to dry weight. Data represent averages and standard deviations: Treatment $\mathrm{A}$ and $\mathrm{C} \mathrm{n}=3$, Treatment $\mathrm{B} \mathrm{n}=2$. 
Table 2: Parameters obtained from AD using Pseudanabaena biomass. Data represent averages and standard deviations. Treatment $A$ and $C n=3$, Treatment $B \mathrm{n}=2$. Superscripts represent a significant difference in the results $(\alpha=0.05)$.

\begin{tabular}{|c|c|c|c|c|c|c|c|}
\hline Treatment & $\begin{array}{l}\text { Carbohydrate } \\
\text { in biomass } \\
(\% \mathrm{DW})\end{array}$ & $\begin{array}{c}\text { COD/VS } \\
\text { ratio* }^{*} \\
\left(\mathrm{~g} \mathrm{~g}^{-1}\right)\end{array}$ & $\begin{array}{c}\text { Methane } \\
\text { yield } \\
\left(m L \text { CH}_{4}\right. \\
\left.\text { g }^{-1} \text { COD }_{\text {in }}\right)\end{array}$ & $\begin{array}{c}\text { Methane } \\
\text { concentration } \\
\text { in biogas } \\
\left(\% \mathbf{v ~ v}^{-1}\right)\end{array}$ & $\begin{array}{c}k_{H} \\
\left(d^{-1} y^{-1}\right)^{* *}\end{array}$ & $\begin{array}{c}\mathbf{B}_{\infty} \\
\left(\mathrm{mL} \mathrm{CH}_{4}\right. \\
\mathrm{g}^{-1} \\
\left.\mathrm{COD}_{\text {in }}\right)^{* * * *}\end{array}$ & $\begin{array}{c}\mathbf{R}^{2} \\
\text { model }\end{array}$ \\
\hline A & $23 \% \pm 6.8^{a}$ & 1.8 & $251 \pm 7.2^{\mathrm{a}}$ & $70 \pm 6.3^{\mathrm{a}}$ & $\begin{array}{l}0.18 \pm \\
0.003^{\mathrm{a}}\end{array}$ & $241 \pm 6.7^{a}$ & 0.99 \\
\hline B & $38 \% \pm 3.2^{\mathrm{b}}$ & 1.7 & $226 \pm 5.3^{b}$ & $65 \pm 3.5^{\mathrm{a}}$ & $\begin{array}{c}0.20 \pm \\
0.01^{\mathrm{b}}\end{array}$ & $215 \pm 5.5^{b}$ & 0.99 \\
\hline $\mathrm{C}$ & $61 \% \pm 2.1^{\mathrm{b}}$ & 1.5 & $215 \pm 1.4^{\mathrm{b}}$ & $61 \pm 7.0^{\mathrm{a}}$ & $\begin{array}{l}0.21 \pm \\
0.006^{\mathrm{b}}\end{array}$ & $203 \pm 1.0^{\mathrm{b}}$ & 0.99 \\
\hline
\end{tabular}

${ }^{*}$ Chemical oxygen demand to volatile solids ratio.

${ }^{* *}$ Hydrolysis constant.

${ }^{* * *}$ Theoretical potential methane yield.

Methane yields of lignocellulosic materials, evaluated in batch mode, range from 50 to $500 \mathrm{~mL}$ $\mathrm{CH}_{4} \mathrm{~g}^{-1} \mathrm{VS}_{\mathrm{in}}$, as reviewed by [38]. This high variability can be explained by the biomass composition diversity of the organic substrates, AD conditions (digestion time and temperature, and substrate to inoculum ratio) evaluated or the use of biomass pre-treatments to improve methane yields. A COD/VS ratio of $1.8 \mathrm{~g} \mathrm{~g}^{-1}$ was obtained for Pseudanabaena with $23 \%$ DW carbohydrate (biomass from treatment A), equivalent to $452 \mathrm{~mL} \mathrm{CH}_{4} \mathrm{~g}^{-1} \mathrm{VS}_{\text {in. }}$ Consequently, Pseudanabaena's digestibility is as high as that reported for the former organic substrates; however, additional biomass pre-treatments in Pseudanabaena are not necessary to improve methane yields. 
When compared to eukaryotic microalgae species, Pseudanabaena's methane yields are higher than the reported values of $81-185 \mathrm{~mL} \mathrm{CH}_{4} \mathrm{~g}^{-1} \mathrm{COD}_{\text {in }}$ for the species Chlorella and Scenedesmus, and their consortium including Chlamydomonas (Table 3). Methane yields around $200 \mathrm{~mL} \mathrm{CH}_{4}$ $\mathrm{g}^{-1}$ VS are reported for Nannochloropsis salina [6], and higher methane yields around $500 \mathrm{~mL}$ $\mathrm{CH}_{4} \mathrm{~g}^{-1}$ VS have been reported for the species Dunaliella salina and Chlamydomonas reinhardtii [4]. Compared to cyanobacteria species, Pseudanabaena's methane yields are similar to that of Aphanizomenon ovalisporum, Ananabaena plactonica, and Synechocystis sp. with reported methane yields between 218-261 $\mathrm{mL} \mathrm{CH}_{4} \mathrm{~g}^{-1} \mathrm{COD}_{\text {in }}$ (Table 3). Methane yield of Arthrospira platensis digestion is reported between 318-481 $\mathrm{mL} \mathrm{CH}_{4} \mathrm{~g}^{-1} \mathrm{VS}$ [4,39], similar to that of Pseudanabaena's with $452 \mathrm{~mL} \mathrm{CH}_{4} \mathrm{~g}^{-1} \mathrm{VS}$. The high methane yield of prokaryotic cyanobacteria species, including Pseudanabaena, and few eukaryotic microalgae species, including Chlamydomonas and Dunaliella, may be explained by the presence of a weaker cell wall poor in complex carbohydrates such as hemicellulose, cellulose, or algaenan typically found in most of eukaryotic microalgae species and lignocellulosic materials [4,40]. Although, increases in methane yields $(10-60 \%)$ are attained when biomass is pre-treated [41], additional procedures prior to AD decrease process energy output and increase production costs [14]. Thus, the high digestibility and fast nutrient uptake of Pseudanabaena would represent an advantage for wastewater treatment combined with bioenergy production.

As initially discussed, the highest methane yield of $251 \mathrm{~mL} \mathrm{CH}_{4} \mathrm{~g}^{-1} \mathrm{COD}_{\text {in }}$ was reached for Pseudanabaena biomass with low carbohydrate content (treatment A). In contrast, methane yields decreased while carbohydrate content in biomass increased. Therefore, biomass composition does affect the methane yield. Similarly, as listed Table 3, the methane yield of Anabaena plactonica 
with $63 \%$ DW content of carbohydrate was lower $\left(187 \mathrm{~mL} \mathrm{CH}_{4} \mathrm{~g}^{-1} \mathrm{COD}_{\text {in }}\right)$ than that of Anabaena plactonica with $42 \%$ DW carbohydrate $\left(261 \mathrm{~mL} \mathrm{CH}_{4} \mathrm{~g}^{-1} \mathrm{COD}_{\text {in }}\right)$. Theoretical methane yields of proteins are higher than for carbohydrates: 496 and $415 \mathrm{~mL} \mathrm{CH}_{4} \mathrm{~g}^{-1} \mathrm{VS}$, respectively [42]. Thus, the higher concentration of proteins in Pseudanabaena biomass (treatment A) is related to the higher methane yield observed in these batches. Even though protein-rich substrates are claimed to be detrimental for methanogens' activity due to ammonia toxicity, the low substrate to inoculum ratio used in batch systems reduces this negative effect $[43,44]$. Thus, the combination of these factors explained the higher methane yield obtained from Pseudanabaena with high protein content (treatment A).

In contrast, semi-continuous and continuous $\mathrm{AD}$ of carbohydrate-rich substrates are reported to improve methane yield. Arthrospira platensis co-digestion with beet silage almost doubled its methane yield in a continuous system compared to A. platensis mono-digestion [44]. In another study, when operating a semi-continuous reactor at a hydraulic retention time of 15 days, $A$. platensis carbohydrate-enriched biomass increased methane yield by $35 \%$ for biomass with $60 \%$ DW carbohydrate [11]. It is well known that the hydrolysis stage is the rate-limiting step of the AD process for a given substrate [12]. Similar to a higher methane yield of carbohydrate-rich biomass in continuous AD, the hydrolysis constant calculated for Pseudanabaena digested in batch mode was higher for biomass with higher carbohydrate content (Table 2). Biomass from treatment A, with the lowest carbohydrate content $(23 \% \mathrm{DW})$, had the lowest hydrolysis constant $\left(k_{H}\right)$ of 0.18 day $^{-1}$. This value was statistically different $(p=0.008)$ from the $k_{H}$ of the biomass with higher carbohydrate content: 0.20 and $0.21 \mathrm{day}^{-1}$ for $38 \%$ (treatment B) and $61 \% \mathrm{DW}$ (treatment C) carbohydrates, respectively. Thus, carbohydrate-rich biomass was hydrolysed faster than the 
protein-rich biomass. This behaviour is explained by the fact that a higher $\mathrm{C} / \mathrm{N}$ ratio enhances substrate hydrolysis during AD [41], as observed for Pseudanabaena and other cyanobacteria species when carbohydrate-rich substrates are digested [44,45].

Hydrolysis constants of lignocellulosic material are highly variable due to their diverse biomass composition, values from 0.06 to 0.24 day $^{-1}$ are reported [46]. In case of eukaryotic microalgae and prokaryotic cyanobacteria, very few studies report their hydrolysis constants: GonzálezFernández et al., (2016) reported hydrolysis constants of $0.04-0.20$ day $^{-1}$ for the digestion of Chlorella, Scenedesmus and Chlamydomonas consortium cultivated under different conditions, while for the cyanobacterium Chroococcus sp. and Arthrospira platensis, hydrolysis constants of 0.03 and $0.04 \mathrm{day}^{-1}$, respectively, were reported [44,45]. Thus, hydrolysis constants of 0.18-0.21 day $^{-1}$ found in this study confirm Pseudanabaena as a high hydrolysable substrate suitable for AD. Nonetheless, further studies evaluating $\mathrm{AD}$ of microalgae and cyanobacteria biomass must be implemented to evaluate the influence of biomass macromolecular composition and digestion operational conditions in methane yields. 
Table 3. Literature comparison among cyanobacteria and microalgae species' performance in anaerobic digestion.

\begin{tabular}{|c|c|c|c|c|c|}
\hline Microorganism & $\begin{array}{l}\text { Major biomass } \\
\text { component (\% } \\
\text { DW) }\end{array}$ & $\begin{array}{c}\text { Methane } \\
\text { yield (mL } \\
\mathrm{CH}_{4} \mathrm{~g}^{-1} \\
\left.\mathrm{COD}_{\text {in }}\right)\end{array}$ & $\begin{array}{l}\text { Anaerobic } \\
\text { digestion } \\
\text { time (days) }\end{array}$ & $\begin{array}{c}\text { Methane } \\
\text { concentration in } \\
\text { biogas }\left(\% \mathbf{v ~ v}^{-1}\right)\end{array}$ & Reference \\
\hline $\begin{array}{l}\text { Anabaena } \\
\text { planctonica }\end{array}$ & $\begin{array}{c}63 \% \\
\text { carbohydrate }\end{array}$ & 187 & 22 & 74 & {$[8]$} \\
\hline $\begin{array}{l}\text { Anabaena } \\
\text { planctonica }\end{array}$ & $\begin{array}{c}42 \% \\
\text { carbohydrate }\end{array}$ & 261 & 35 & NA & [9] \\
\hline $\begin{array}{l}\text { Aphanizomenon } \\
\text { ovalisporum }\end{array}$ & $\begin{array}{c}42 \% \\
\text { carbohydrate }\end{array}$ & 223 & 22 & 74 & {$[8]$} \\
\hline $\begin{array}{l}\text { Aphanizomenon } \\
\text { ovalisporum }\end{array}$ & $\begin{array}{c}34 \% \\
\text { carbohydrate }\end{array}$ & 218 & 35 & NA & [9] \\
\hline $\begin{array}{l}\text { Arthrospira } \\
\text { platensis }\end{array}$ & $\begin{array}{l}\quad 60 \% \\
\text { carbohydrate }\end{array}$ & 160 & 15 & NA & {$[11]$} \\
\hline Borzia trilocularis & $63 \%$ protein & 168 & 22 & 76 & {$[8]$} \\
\hline Chlorella vulgaris & $65 \%$ protein & 125 & 22 & 76 & {$[8]$} \\
\hline Chlorella vulgaris & $\begin{array}{c}34 \% \\
\text { carbohydrate }\end{array}$ & 185 & 35 & NA & [9] \\
\hline $\begin{array}{l}\text { Chlorella vulgaris, } \\
\text { Scenedesmus }\end{array}$ & & & & & \\
\hline $\begin{array}{l}\text { obliquus and } \\
\text { Chlamydomonas } \\
\text { reindhardtii }\end{array}$ & $57 \%$ protein & 171 & 35 & NA & {$[10]$} \\
\hline $\begin{array}{l}\text { Chlorella vulgaris, } \\
\text { Scenedesmus }\end{array}$ & $\begin{array}{l}50 \% \\
\text { carbohydrate }\end{array}$ & 146 & 35 & 67 & [47] \\
\hline
\end{tabular}


obliquus and

Chlamydomonas

reindhardtii

$\begin{array}{lccccc}\text { Pseudanabaena sp. } & \begin{array}{c}23 \% \\ \text { carbohydrate }\end{array} & 251 & 29 & 70 & \text { This study } \\ \text { Synechocystis } s p . & 65 \% \text { protein } & 220 & 22 & 75 & \text { [8] } \\ \text { Scenedesmus } s p . & \text { NA } & 81 & 34 & 62 & \text { [7] }\end{array}$

NA refers to not available information.

\section{Conclusions}

Nutrients availability in the cultivation medium affects the macromolecular biomass composition of cyanobacteria. In this study, the cyanobacterium Pseudanabaena was cultivated under limiting nitrogen concentrations to promote the accumulation of carbohydrates. When only $14 \mathrm{mg} \mathrm{N} \mathrm{L}^{-1}$ were supplied in the cultivation medium, up to $61 \%$ DW carbohydrate were accumulated in Pseudanabaena biomass. In contrast, nitrogen availability of 42 and $56 \mathrm{mg} \mathrm{N} \mathrm{L}^{-1}$ decreased carbohydrate content in biomass to 38 and $23 \%$ DW, respectively. Nevertheless, biomass with the lowest carbohydrate content $(23 \% \mathrm{DW})$ resulted in the highest methane yield of $251 \mathrm{~mL} \mathrm{CH}_{4} \mathrm{~g}^{-1}$ $\mathrm{COD}_{\text {in }}$, followed by 226 and $215 \mathrm{~mL} \mathrm{CH}_{4} \mathrm{~g}^{-1} \mathrm{COD}_{\text {in }}$ for the biomass with 38 and $61 \% \mathrm{DW}$ carbohydrates, respectively. Despite biomass composition, high hydrolysis constants of 0.18-0.21 day $^{-1}$ were determined indicating that Pseudanabaena biomass does not hamper the hydrolytic stage of AD. Thus, contrary to eukaryotic microalgae or lignocellulosic materials, cyanobacteria exhibit a high methane yield and require no pre-treatments prior AD. 


\section{Author's contributions:}

Study's conception and design: CGF, KM, SPCB, JAM. Collection and assembly of data: SPCB,

JAM. Data interpretation, manuscript drafting, and final approval of the article: SPCB, JAM, CGF, KM. Administrative and technical support, and obtaining funding: GCF, KM.

\section{References}

[1] WBA, WBA GLOBAL BIOENERGY STATISTICS 2017, (2017). www.worldbioenergy.org (accessed July 19, 2018).

[2] S. Achinas, V. Achinas, G.J.W. Euverink, A Technological Overview of Biogas Production from Biowaste, Engineering. 3 (2017) 299-307. doi:10.1016/J.ENG.2017.03.002.

[3] A. Meneses-Jácome, R. Diaz-Chavez, H.I. Velásquez-Arredondo, D.L. Cárdenas-Chávez, R. Parra, A.A. Ruiz-Colorado, Sustainable Energy from agro-industrial wastewaters in Latin-America, Renew. Sustain. Energy Rev. 56 (2016) 1249-1262. doi:10.1016/J.RSER.2015.12.036.

[4] J.H. Mussgnug, V. Klassen, A. Schlüter, O. Kruse, Microalgae as substrates for fermentative biogas production in a combined biorefinery concept, J. Biotechnol. 150 (2010) 51-56. doi:10.1016/J.JBIOTEC.2010.07.030.

[5] L. Brennan, P. Owende, Biofuels from microalgae-A review of technologies for production, processing, and extractions of biofuels and co-products, Renew. Sustain. Energy Rev. 14 (2010) 557-577. doi:10.1016/j.rser.2009.10.009.

[6] S. Schwede, Z.-U. Rehman, M. Gerber, C. Theiss, R. Span, Effects of thermal pretreatment on anaerobic digestion of Nannochloropsis salina biomass, Bioresour. Technol. 143 (2013) 505-511. doi:10.1016/J.BIORTECH.2013.06.043.

[7] C. González-Fernández, B. Sialve, N. Bernet, J.P. Steyer, Comparison of ultrasound and thermal pretreatment of Scenedesmus biomass on methane production, Bioresour. Technol. 110 (2012) 610-616. doi:10.1016/j.biortech.2012.01.043.

[8] L. Mendez, A. Mahdy, M. Ballesteros, C. Gonzalez-Fernandez, Chlorella vulgaris vs cyanobacterial biomasses: Comparison in terms of biomass productivity and biogas yield, 
Energy Convers. Manag. 92 (2015) 137-142. doi:10.1016/j.enconman.2014.11.050.

[9] L. Mendez, B. Sialve, E. Tomás-Pejó, M. Ballesteros, J.P. Steyer, C. González-Fernández, Comparison of Chlorella vulgaris and cyanobacterial biomass: cultivation in urban wastewater and methane production, Bioprocess Biosyst. Eng. 39 (2016) 703-712. doi:10.1007/s00449-016-1551-7.

[10] B. Molinuevo-Salces, A. Mahdy, M. Ballesteros, C. González-Fernández, From piggery wastewater nutrients to biogas: Microalgae biomass revalorization through anaerobic digestion, Renew. Energy. 96 (2016) 1103-1110. doi:10.1016/J.RENENE.2016.01.090.

[11] G. Markou, I. Angelidaki, D. Georgakakis, Carbohydrate-enriched cyanobacterial biomass as feedstock for bio-methane production through anaerobic digestion, Fuel. 111 (2013) 872-879. doi:10.1016/j.fuel.2013.04.013.

[12] F. Passos, E. Uggetti, H. Carrère, I. Ferrer, Pretreatment of microalgae to improve biogas production: A review, Bioresour. Technol. 172 (2014) 403-412. doi:10.1016/J.BIORTECH.2014.08.114.

[13] R. Ganesh Saratale, G. Kumar, R. Banu, A. Xia, S. Periyasamy, G. Dattatraya Saratale, A critical review on anaerobic digestion of microalgae and macroalgae and co-digestion of biomass for enhanced methane generation, Bioresour. Technol. 262 (2018) 319-332. doi:10.1016/J.BIORTECH.2018.03.030.

[14] L. Mendez, A. Mahdy, R.A. Timmers, M. Ballesteros, C. González-Fernández, Enhancing methane production of Chlorella vulgaris via thermochemical pretreatments, Bioresour. Technol. 149 (2013) 136-141. doi:10.1016/j.biortech.2013.08.136.

[15] C. González-Fernández, B. Sialve, N. Bernet, J.P. Steyer, Thermal pretreatment to improve methane production of Scenedesmus biomass, Biomass and Bioenergy. 40 (2012) 105-111. doi:10.1016/j.biombioe.2012.02.008.

[16] M.N.I. Siddique, Z.A. Wahid, Achievements and perspectives of anaerobic co-digestion: A review, J. Clean. Prod. 194 (2018) 359-371. doi:10.1016/J.JCLEPRO.2018.05.155.

[17] K. Hagos, J. Zong, D. Li, C. Liu, X. Lu, Anaerobic co-digestion process for biogas production: Progress, challenges and perspectives, Renew. Sustain. Energy Rev. 76 (2017) 1485-1496. doi:10.1016/J.RSER.2016.11.184.

[18] O. Depraetere, F. Deschoenmaeker, H. Badri, P. Monsieurs, I. Foubert, N. Leys, R. Wattiez, K. Muylaert, Trade-Off between Growth and Carbohydrate Accumulation in 
Nutrient-Limited Arthrospira sp. PCC 8005 Studied by Integrating Transcriptomic and Proteomic Approaches, PLoS One. 10 (2015) e0132461.

doi:10.1371/journal.pone.0132461.

[19] O. Ciferri, Spirulina, the edible microorganism., Microbiol. Rev. 47 (1983) 551-78. http://www.ncbi.nlm.nih.gov/pubmed/6420655 (accessed January 24, 2017).

[20] D. García, E. Posadas, C. Grajeda, S. Blanco, S. Martínez-Páramo, G. Acién, P. GarcíaEncina, S. Bolado, R. Muñoz, Comparative evaluation of piggery wastewater treatment in algal-bacterial photobioreactors under indoor and outdoor conditions, Bioresour. Technol. 245 (2017) 483-490. doi:10.1016/J.BIORTECH.2017.08.135.

[21] D. García, C. Alcántara, S. Blanco, R. Pérez, S. Bolado, R. Muñoz, Enhanced carbon, nitrogen and phosphorus removal from domestic wastewater in a novel anoxic-aerobic photobioreactor coupled with biogas upgrading, Chem. Eng. J. 313 (2017) 424-434. doi:10.1016/J.CEJ.2016.12.054.

[22] J. Liu, W. Vyverman, Differences in nutrient uptake capacity of the benthic filamentous algae Cladophora sp., Klebsormidium sp. and Pseudanabaena sp. under varying N/P conditions, Bioresour. Technol. 179 (2015) 234-242.

doi:10.1016/J.BIORTECH.2014.12.028.

[23] M.L. Serejo, E. Posadas, M.A. Boncz, S. Blanco, P. García-Encina, R. Muñoz, Influence of Biogas Flow Rate on Biomass Composition During the Optimization of Biogas Upgrading in Microalgal-Bacterial Processes, Environ. Sci. Technol. 49 (2015) 32283236. doi:10.1021/es5056116.

[24] L. Marbelia, M. Mulier, D. Vandamme, K. Muylaert, A. Szymczyk, I.F.J. Vankelecom, Polyacrylonitrile membranes for microalgae filtration: Influence of porosity, surface charge and microalgae species on membrane fouling, Algal Res. 19 (2016) 128-137. doi:10.1016/J.ALGAL.2016.08.004.

[25] I. Canto, D. Loura, J.P. Dubacq, J.C. Thomas, The Effects of Nitrogen Deficiency on Pigments and Lipids of Cyanobacteria, Plant Physiol. 83 (1987) 838-843. https://www.ncbi.nlm.nih.gov/pmc/articles/PMC1056460/pdf/plntphys00612-0128.pdf (accessed February 22, 2018).

[26] A. Beuckels, Removal and reuse of phosphorus from wastewater using microalgae, KU Leuven, 2015. https://limo.libis.be/primo- 
explore/fulldisplay?docid=LIRIAS1741194\&context=L\&vid=Lirias\&search_scope=Liria s\&tab=default_tab\&lang=en_US (accessed July 17, 2019).

[27] U. Nübel, F. Garcia-Pichel, G. Muyzer, PCR primers to amplify 16 S rRNA genes from cyanobacteria., Appl. Environ. Microbiol. 63 (1997) 3327-32.

http://www.ncbi.nlm.nih.gov/pubmed/9251225 (accessed August 12, 2019).

[28] R.R.L. Guillard, C.J. Lorenzen, Yellow-green algae with clorophyllide C, J. Phycol. 8 (1972) 10-14. doi:10.1111/j.1529-8817.1972.tb03995.x.

[29] I. Díaz, A. Donoso-Bravo, M. Fdz-Polanco, Effect of microaerobic conditions on the degradation kinetics of cellulose, Bioresour. Technol. 102 (2011) 10139-10142. doi:10.1016/J.BIORTECH.2011.07.096.

[30] M. DuBois, K.A. Gilles, J.K. Hamilton, P.A. Rebers, F. Smith, Colorimetric Method for Determination of Sugars and Related Substances, Anal. Chem. 28 (1956) 350-356. doi:10.1021/ac60111a017.

[31] O.H. Lowry, N.J. Rosebrough, A.L. Farr, R.J. Randall, Protein measurement with the Folin phenol reagent, J. Biol. Chem. (1951) 265-275.

[32] S.K. Mishra, W.I. Suh, W. Farooq, M. Moon, A. Shrivastav, M.S. Park, J.-W. Yang, Rapid quantification of microalgal lipids in aqueous medium by a simple colorimetric method, Bioresour. Technol. 155 (2014) 330-333. doi:10.1016/j.biortech.2013.12.077.

[33] W.P. Robarge, A. Edwards, B. Johnson, Water and waste water analysis for nitrate via nitration of salicylic acid, Commun. Soil Sci. Plant Anal. 14 (1983) 1207-1215. doi:10.1080/00103628309367444.

[34] S. Kumar Saha, L. Uma, G. Subramanian, Nitrogen stress induced changes in the marine cyanobacterium Oscillatoria willei BDU 130511, FEMS Microbiol. Ecol. 45 (2003) 263272. doi:10.1016/S0168-6496(03)00162-4.

[35] C. Cavinato, A. Ugurlu, I. de Godos, E. Kendir, C. Gonzalez-Fernandez, Biogas production from microalgae, Microalgae-Based Biofuels Bioprod. (2017) 155-182. doi:10.1016/B978-0-08-101023-5.00007-8.

[36] E. Touloupakis, B. Cicchi, A.M.S. Benavides, G. Torzillo, Effect of high pH on growth of Synechocystis sp. PCC 6803 cultures and their contamination by golden algae (Poterioochromonas sp.), Appl. Microbiol. Biotechnol. 100 (2016) 1333-1341. doi:10.1007/s00253-015-7024-0. 
[37] A. Molino, A. Iovine, P. Casella, S. Mehariya, S. Chianese, A. Cerbone, J. Rimauro, D. Musmarra, Microalgae Characterization for Consolidated and New Application in Human Food, Animal Feed and Nutraceuticals, Int. J. Environ. Res. Public Health. 15 (2018) 2436. doi:10.3390/ijerph15112436.

[38] F. Raposo, M.A. De la Rubia, V. Fernández-Cegrí, R. Borja, Anaerobic digestion of solid organic substrates in batch mode: An overview relating to methane yields and experimental procedures, Renew. Sustain. Energy Rev. 16 (2012) 861-877. doi:10.1016/J.RSER.2011.09.008.

[39] C. González-Fernández, L. Méndez, E. Tomas-Pejó, M. Ballesteros, Biogas and Volatile Fatty Acids Production: Temperature as a Determining Factor in the Anaerobic Digestion of Spirulina platensis, Waste and Biomass Valorization. (2018) 1-9. doi:10.1007/s12649018-0275-0.

[40] P.-H. Baudelet, G. Ricochon, M. Linder, L. Muniglia, A new insight into cell walls of Chlorophyta, Algal Res. 25 (2017) 333-371. doi:10.1016/J.ALGAL.2017.04.008.

[41] A.J. Ward, D.M. Lewis, F.B. Green, Anaerobic digestion of algae biomass: A review, Algal Res. 5 (2014) 204-214. doi:10.1016/J.ALGAL.2014.02.001.

[42] I. Angelidaki, W. Sanders, Assessment of the anaerobic biodegradability of macropollutants, Rev. Environ. Sci. Bio/Technology. 3 (2004) 117-129. doi:10.1007/s11157-004-2502-3.

[43] A.E. Inglesby, M.J. Griffiths, S.T.L. Harrison, R.P. van Hille, Anaerobic digestion of Spirulina sp. and Scenedesmus sp.: a comparison and investigation of the impact of mechanical pre-treatment, J. Appl. Phycol. 27 (2015) 1891-1900. doi:10.1007/s10811015-0669-3.

[44] C. Herrmann, N. Kalita, D. Wall, A. Xia, J.D. Murphy, Optimised biogas production from microalgae through co-digestion with carbon-rich co-substrates, Bioresour. Technol. 214 (2016) 328-337. doi:10.1016/J.BIORTECH.2016.04.119.

[45] S.K. Prajapati, A. Malik, V.K. Vijay, T.R. Sreekrishnan, Enhanced methane production from algal biomass through short duration enzymatic pretreatment and codigestion with carbon rich waste, RSC Adv. 5 (2015) 67175-67183. doi:10.1039/C5RA12670C.

[46] Y. Li, R. Zhang, G. Liu, C. Chen, Y. He, X. Liu, Comparison of methane production potential, biodegradability, and kinetics of different organic substrates, Bioresour. 
Technol. 149 (2013) 565-569. doi:10.1016/J.BIORTECH.2013.09.063.

[47] C. González-Fernández, A. Mahdy, I. Ballesteros, M. Ballesteros, Impact of temperature and photoperiod on anaerobic biodegradability of microalgae grown in urban wastewater, Int. Biodeterior. Biodegradation. 106 (2016) 16-23. doi:10.1016/J.IBIOD.2015.09.016. 